\title{
The effect of grain processing and grain source on performance, rumen fermentation and selected blood metabolites of Holstein calves
}

\author{
M. Rezapour', Y. Chashnidel ${ }^{1,3}$, E. Dirandeh ${ }^{1,3}$, B. Shohreh ${ }^{1}$ and A.H. Ghaffari ${ }^{2}$ \\ ${ }^{1}$ Sari Agricultural Science and Natural Resources University, Department of Animal Science \\ 578 Sari, Iran \\ ${ }^{2}$ Ferdowsi University of Mashhad, College of Agriculture, Department of Animal Sciences \\ 91775-1163 Mashhad, Iran
}

KEY WORDS: calf, maize, barley, physical form, growth, weaning

Received: 29 September 2015

Revised: $\quad 17$ May 2016

Accepted: 26 August 2016

${ }^{3}$ Corresponding author: e-mail: ychashnidel2002@yahoo.com; dirandeh@gmail.com

\begin{abstract}
The aim of the study was to determine the effects of type of grain processing and grain source on growth performance of calves. Thirty-two male Holstein calves were randomly assigned to 1 of 4 treatments differing in type of grain processing and grain source: CON - ground maize + ground barley, DMGB - dry-rolled maize + ground barley, GMDB - ground maize + dry-rolled barley, and DMDB - dry-rolled maize + dry-rolled barley. All calves were fed for 14 days (starting from day 4 of experiment) and weaned on 60 day of age and remained in the study until day 74 . It was obtained that final and weaning body weights were higher in DMGB and DMDB groups in comparison to CON group. The total dry matter intake was greater in calves fed DMGB diet than in those fed CON diet. Averaged daily gain (ADG) was greater in calves fed DMDB diet than in those fed CON diet during the pre-weaning and overall periods, whereas during post-weaning period the ADG was greater in DMGB group in comparison to CON treatment. Ruminal $\mathrm{pH}$ was greater in DMGB and DMDB groups as compared to other groups on days 46 and 60 , while ruminal $\mathrm{NH}_{3}-\mathrm{N}$ content was decreased in DMGB and GMDB groups. On day 46 glucose level was decreased in blood of animals fed all examined treatments. Blood $\beta$-hydroxybutyrate level was greater $(P=0.01)$ in group fed DMGB diet in comparison to CON and GMDB groups at weaning. In conclusion, starter diets containing dry-rolling maize and barley can better improve calf performance than diets containing ground maize/ ground barley.
\end{abstract}

\section{Introduction}

Physical and metabolic development of the reticulorumen is important for both easing the transition from pre-ruminant to mature ruminant state and improving calf health (Khan et al., 2011). The preweaning growth of calves is a complex process in- volving interactions among nutritional components and physiological signals, which mostly depend on feeding management (Baldwin et al., 2004). Cereal grains are the primary source of starch in ruminant diets. Maize grain is more slowly fermented than barley and slower rates of digestion increase the amount of starch bypassing the rumen (Khan et al., 2007). 
Differences in starch shape, granule size, and interactions between amylose and surface compounds can alter the rate of enzymatic digestion of maize and barley starches (Kotarski et al., 1992). Starch digested in the small intestine can produce more energy than rumen fermentation (glucose more efficient than volatile fatty acids; VFA); therefore, the site of starch digestion along the gastrointestinal tract (GIT) affects calf performance (Khan et al., 2007).

Mechanical alterations during processing increase the surface of exposure area and improve ruminal, intestinal and total tract starch digestibility of seed grains (Lesmeister and Heinrichs, 2004). Processing (e.g., grinding, rolling or pelleting) is necessary to break the pericarp of the grain in order to improve its digestibility (Owens et al., 1997), although it may also lead to the increased risk of acidosis, depending on the processing extent. Grinding and pelleting increase microbial fermentation by reducing particle size and/or promoting starch gelatinization (Bertipaglia et al., 2010). Cereal rolling would ensure larger particle size than grinding (Beauchemin et al., 2001; Dehghan-banadaky et al., 2007), and therefore is an interesting, better than grinding or pelleting, alternative for preventing ruminal acidosis (Gimeno et al., 2015).

Porter et al. (2007) reported greater average daily gain (ADG), starter intake, and earlier rumination time in neonatal calves fed coarse meal diet vs pelleted fine particle diet. However, a minimal particle size is required because consumption of diets with too many fine particles can lead to a rumen parakeratosis (Greenwood et al., 1997). Data reported by Porter et al. (2007) suggested that ruminal parakeratosis and bloat are minimized when $75 \%$ of the particles in a starter exceed $1190 \mu \mathrm{m}$ in diameter. The highest intake was found in animals fed diets containing dry-rolled grains, followed by whole, steam rolled and steam-flaked grains, with finely ground grains resulting in the lowest feed intake (Zhang et al., 2010).

Although, some information about the physical form of starter is available in the literature, the industry could benefit from a more systemic approach to research which would confirm which grain processing is the best for calf performance. So, the objective of our study was to evaluate the effects of grain processing (grinding vs dry-rolling) on performance, structural growth, rumen fermentation and selected blood metabolites of Holstein dairy calves during the transition from liquid to solid feed.

\section{Material and methods}

\section{Calves, management and treatments}

All experimental procedures and animal management were in accordance with the guidelines of the Iranian Council of Animal Care (1995).

The study was carried out in the Mahdasht Milk and Meat Company (Sari, Mazandaran, Iran) from February to May 2014. The thirty-two male Holstein dairy calves (4-day old, $45 \pm 3 \mathrm{~kg}$ body weight (BW)) used in this study were separated from their dams within $2 \mathrm{~h}$ after birth, weighed and housed in individual pens $(1.5 \times 2.5 \mathrm{~m})$ bedded with sand, which was renewed every $24 \mathrm{~h}$. The animals were fed 4.01 of colostrum at each of the first two feedings (i.e. within $1.5 \mathrm{~h}$ of life and $12 \mathrm{~h}$ after the first feeding). Colostrum feeding was carried out for the first 3 days of life. Calves received $41 \cdot \mathrm{d}^{-1}$ of milk containing: \%: $3.09 \pm 0.12$ fat, $3.12 \pm 0.06$ crude protein $(\mathrm{CP}), 4.67 \pm 0.06$ lactose and $11.62 \pm 0.16$ total solids twice a day (7:30 and 16:00) from 4 to 50 day of age and then $21 \cdot \mathrm{d}^{-1}$ of milk from 50 to 59 day of age. The animals were randomly assigned to 1 of 4 dietary treatments: $\mathrm{CON}$ - ground maize + ground barley, DMGB - dry-rolled maize + ground barley, GMDB - ground maize + dryrolled barley, and DMDB - dry-rolled maize + dryrolled barley, with all other components in a meal form $(\leq 2 \mathrm{~mm})$. All calves were weaned on 60 day of age and remained in the study until 74 day of age. Grains (maize or barley) were finely ground by a hammer mill (model 5543 GEN, Isfahan Dasht, Isfahan, Iran) with $1 \mathrm{~mm}$ screen size. Dry-rolled grains were prepared by passing barley and maize through rollers to obtain coarsely broken kernels of respective density $0.45 \mathrm{~kg} \cdot 1^{-1}$ and $0.54 \mathrm{~kg} \cdot 1^{-1}$. The calves had free access to water from a drinker in each pen and starters were fed ad libitum (orts did not exceed at least 10\%). Starter diets (Table 1) were formulated according to the Cornell Net Carbohydrate and Protein System (Fox et al., 2000).

\section{Sampling}

Calf starter intakes were measured daily and individual BW was recorded every week. Pre-weaning, post-weaning and overall means of ADG and feed efficiency (FE, $\mathrm{kg}$ of BW gain per kg of dry matter (DM) and liquid feeds) were also calculated. Feed samples were collected every week and stored at $-18{ }^{\circ} \mathrm{C}$ until chemical analysis. Body measurements including heart girth, hip height and hip width were performed according to the method described by Khan et al. (2007). To determine the milk composition 
Table 1. Ingredient and chemical composition of experimental starter concentrates (diets)

\begin{tabular}{lllll}
\hline \multirow{2}{*}{ Indices } & \multicolumn{5}{l}{ Treatment } \\
\cline { 2 - 5 } & CON & DMGB & GMDB & DMDB \\
\hline Ingredients, \% & & & & \\
ground barley & 23.4 & 23.4 & - & - \\
dry-rolled barley & - & - & 23.4 & 23.4 \\
ground maize & 26.0 & - & 26.0 & - \\
dry-rolled maize & - & 26.0 & - & 26.0 \\
soyabean meal, 45\% CP & 37.3 & 37.3 & 37.3 & 37.3 \\
fishmeal & 1 & 1 & 1 & 1 \\
wheat bran & 9 & 9 & 9 & 9 \\
calcium carbonate & 0.6 & 0.6 & 0.6 & 0.6 \\
di-calcium phosphate & 0.5 & 0.5 & 0.5 & 0.5 \\
sodium bicarbonate & 0.5 & 0.5 & 0.5 & 0.5 \\
vitamin and mineral premix & 1.0 & 1.0 & 1.0 & 1.0 \\
NaCl & 0.7 & 0.7 & 0.7 & 0.7 \\
Chemical composition & & & & \\
dry matter (DM), \% feed & 91.1 & 91.2 & 90.1 & 91.0 \\
crude protein (CP), \% DM & 22.0 & 21.7 & 22.2 & 21.8 \\
neutral detergent fibre & 22.9 & 23.1 & 22.9 & 23.0 \\
$\quad$ (NDF), \% DM & & & & \\
NFC ${ }^{3}, \%$ DM & 45.0 & 45.2 & 44.8 & 45.2 \\
ether extract, \% DM & 4.1 & 3.9 & 4.0 & 3.9 \\
calcium ${ }^{4}, \%$ DM & 0.80 & 0.80 & 0.80 & 0.80 \\
phosphorus,$\%$ DM & 0.67 & 0.67 & 0.67 & 0.67 \\
Particle size ${ }^{5}$, mm & 1.05 & 1.87 & 1.23 & 1.98 \\
\hline
\end{tabular}

${ }^{1}$ treatments: CON - ground maize + ground barley, DMGB - dryrolled maize + ground barley, GMDB - ground maize + dry-rolled barley, and DMDB - dry-rolled maize + dry-rolled barley; ${ }^{2}$ premix contained per kg: mg: Ca 800, P 80, Mg 100, Cu 10, Mn 18, Zn 35.2, Co 0.12 , I 0.28 , Se 0.17 ; IU: vit. A 3,000, vit. D 800 , vit. E 6 on a DM basis; ${ }^{3} \mathrm{NFC}$ - non-fibrous carbohydrate was calculated as $100-$ $\left(\mathrm{CP}+\mathrm{NDF}+\right.$ ether extract + ash) (NRC, 2001); ${ }^{4}$ calculated from NRC (2001); ${ }^{5}$ geometric mean particle sizes calculated as described by ASAE (1983)

(fat, CP, lactose and total solids), samples were collected twice a week in the morning and in the afternoon of the same day and preserved using bronopol and stored at $8^{\circ} \mathrm{C}$ until analysis by Milkoscan (Foss Electric, Hillerød, Denmark).

Rumen fluid was sampled on days 46, 60 and 74 by a stomach tube fitted to a vacuum pump at $3-4 \mathrm{~h}$ after feeding, and rumen $\mathrm{pH}$ was measured immediately (pH meter Model-350, JENMAY, Stone, UK). Rumen contents were squeezed through a 4-layer cheesecloth and $15 \mathrm{ml}$ of the rumen fluid was acidified with $3 \mathrm{ml}$ of $6 \mathrm{~N}$ sulphuric acids and stored $\left(-18^{\circ} \mathrm{C}\right)$ until $\mathrm{NH}_{3}-\mathrm{N}$ analyses were conducted. On day 46, 60 and 74 of age, blood samples $(20 \mathrm{ml})$ were collected $3 \mathrm{~h}$ after morning feeding via jugular catheter into evacuated tubes containing ethylene diamine tetra acetic acid (EDTA; Becton Dickinson Vacutainer Systems, Franklin Lakes, NJ, USA). The samples were centrifuged at $3000 \mathrm{~g}$ for $10 \mathrm{~min}$ and serum was partitioned into aliquots and stored at $-20^{\circ} \mathrm{C}$ until analysis.

\section{Chemical analyses}

Subsamples of feeds and refusals were mixed thoroughly and dried at $55^{\circ} \mathrm{C}$ for $48 \mathrm{~h}$ and then ground to pass a $1 \mathrm{~mm}$ screen in a Wiley mill (Ogaw Seiki Co., Ltd., Tokyo, Japan) before chemical analyses for DM content (method 934.01; AOAC, 1990), and crude protein (method 988.05; AOAC, 1990) was determined by the Kjeldahl method. The neutral detergent fibre (NDF) content was determined according to the method of Van Soest et al. (1991) using a heat stable amylase (A-3306, Sigma Chemical Co., St. Louis, MO, USA) and sodium sulphite in the NDF procedure. Non-fibre carbohydrate (NFC) was calculated as: $100-(\% \mathrm{NDF}+\% \mathrm{CP}+\%$ ether extract $+\%$ ash). Ether extract was analysed according to AOAC (1990) using a Tecator Soxtec System HT 1043 extraction unit (Tecator; Foss North America, Eden Prairie, MN, USA). $\mathrm{NH}_{3}-\mathrm{N}$ content in the rumen was analysed using a Kjeldahl assay (AOAC International, 2002). Plasma concentrations of $\beta$-hydroxybutyrate (BHBA) were determined by enzymatic analysis (BHBA dehydrogenase; kit No. 310; Sigma Chemical Co., St. Louis, MO, USA). Plasma glucose concentration and blood urea nitrogen (BUN) were determined by an automated biochemical analyzer (Technicon RA 1000; Bayer, NY, USA) using commercial kits (Pars Azmoon Co., Tehran, Iran) according to the manufacturer's instructions.

\section{Statistical analysis}

Data was analysed separately for the pre-weaning (1 -59 day of age), post-weaning (60-74 day of age), and overall (1-74 day of age) periods. DM intake, $\mathrm{BW}, \mathrm{ADG}, \mathrm{FE}$ and blood variables (BHBA and glucose concentrations were analysed by the MIXED procedures of SAS (version 9.2, SAS Institute Inc., Cary, NC, USA) considering the treatments as a fixed effect and the animal as a random effect. Initial BW and structural growth were considered as covariates for the final weight and growth analysis. The effect of dietary treatment on the categorical responses related to faecal score was tested using the GLIMMIX procedure of SAS (version 9.2). The measurements recorded at different weeks were considered as repeated measures using a first-order autoregressive type 1 covariance structure. When differences were detected in the dietary treatments or interactions, means separation was conducted using a Duncan's adjustment for the probability. Significance was declared at $P \leq 0.05$ and trends were considered when $0.05<P<0.10$. 


\section{Results}

Body weight at birth did not differ among treatments, whereas BW at weaning (day 60) and on the last day of the experiment (day 74) was greater in DMGB and DMDB groups in comparison to CON group (Table 2). Starter intake increased in calves with advancing age $(P<0.05$ according to repeated measured ANOVA). The data show that calves fed DMDB and DMGB had greater $(P<0.01)$ starter intake in comparison to $\mathrm{CON}$ group in all examined periods (Table 2). Total DMI was greater in DMDB group in comparison to CON also in all examined periods, whereas total DMI observed in DMGB group was greater only in the post-weaning period in comparison to CON group (Table 2). ADG was greater $(P=0.02)$ in calves fed DMDB than CON diet during the pre-weaning and overall periods,

Table 2. Effect of dietary treatment on body weight (BW), average daily gain (ADG), starter intake, total dry matter intake (DMI), feed efficiency and faecal score of calves

\begin{tabular}{|c|c|c|c|c|c|c|}
\hline \multirow{2}{*}{ Indices } & \multicolumn{4}{|c|}{ Treatment $^{1}$} & \multirow{2}{*}{ SEM } & \multirow{2}{*}{$P$-value } \\
\hline & $\overline{\mathrm{CON}}$ & DMGB & GMDB & DMDB & & \\
\hline \multicolumn{7}{|l|}{ BW, kg } \\
\hline initial & 45.8 & 45.2 & 45.1 & 45.1 & 2.70 & 0.99 \\
\hline weaning & $78.0^{\mathrm{b}}$ & $88.3^{\mathrm{a}}$ & $84.4^{\mathrm{ab}}$ & $90.6^{\mathrm{a}}$ & 2.87 & 0.04 \\
\hline final & $92.9^{\mathrm{b}}$ & $109.4^{a}$ & $104.9^{\mathrm{ab}}$ & $111.5^{\mathrm{a}}$ & 3.84 & 0.02 \\
\hline \multicolumn{7}{|c|}{ Starter intake, $\mathrm{kg} \cdot \mathrm{d}^{-1}$} \\
\hline $\begin{array}{l}\text { pre-weaning } \\
\text { (days } 4 \text {-59) }\end{array}$ & $0.60^{c}$ & $0.93^{b}$ & $0.87^{b c}$ & $1.26^{\mathrm{a}}$ & 0.10 & $<0.01$ \\
\hline $\begin{array}{l}\text { post-weaning } \\
\text { (days } 60-74 \text { ) }\end{array}$ & $2.12^{b}$ & $2.84^{a}$ & $2.55^{\mathrm{ab}}$ & $3.01^{\mathrm{a}}$ & 0.18 & 0.02 \\
\hline $\begin{array}{l}\text { overall } \\
\text { (days } 4 \text { - 74) }\end{array}$ & $0.91^{b}$ & $1.35^{\mathrm{a}}$ & $1.26^{\mathrm{ab}}$ & $1.55^{\mathrm{a}}$ & 0.12 & 0.01 \\
\hline \multicolumn{7}{|c|}{ Total DMI, $\mathrm{kg} \cdot \mathrm{d}^{-1}$} \\
\hline $\begin{array}{l}\text { pre-weaning } \\
\text { (days 4-59) }\end{array}$ & $1.19^{b}$ & $1.52^{\mathrm{ab}}$ & $1.45^{\mathrm{ab}}$ & $1.84^{a}$ & 0.12 & 0.02 \\
\hline $\begin{array}{l}\text { post-weaning } \\
\text { (days } 60-74 \text { ) }\end{array}$ & $2.12^{b}$ & $2.84^{\mathrm{a}}$ & $2.55^{\mathrm{ab}}$ & $3.01^{a}$ & 0.18 & 0.02 \\
\hline $\begin{array}{l}\text { overall } \\
\text { (days } 4-74 \text { ) }\end{array}$ & $1.38^{b}$ & $1.83^{a b}$ & $1.73^{\mathrm{ab}}$ & $2.02^{\mathrm{a}}$ & 0.14 & 0.04 \\
\hline $\begin{array}{l}\text { ADG, } \mathrm{kg} \cdot \mathrm{d}^{-1} \\
\text { pre-weaning } \\
\text { (days } 4-59 \text { ) }\end{array}$ & $0.53^{b}$ & $0.72^{\mathrm{ab}}$ & $0.66^{a b}$ & $0.76^{\mathrm{a}}$ & 0.05 & 0.02 \\
\hline $\begin{array}{l}\text { post-weaning } \\
\text { (days } 60-74 \text { ) }\end{array}$ & $1.07^{b}$ & $1.52^{\mathrm{a}}$ & $1.46^{\mathrm{ab}}$ & $1.49^{\mathrm{ab}}$ & 0.11 & 0.03 \\
\hline $\begin{array}{l}\text { overall } \\
\text { (days } 4 \text { - 74) }\end{array}$ & $0.61^{\mathrm{b}}$ & $0.83^{a b}$ & $0.83^{\mathrm{ab}}$ & $0.88^{\mathrm{a}}$ & 0.05 & 0.02 \\
\hline $\begin{array}{l}\mathrm{FE}^{2} \\
\text { (days } 4-74 \text { ) }\end{array}$ & 0.47 & 0.45 & 0.46 & 0.44 & 0.03 & 0.91 \\
\hline $\begin{array}{l}\text { Faecal score } \\
\text { (days } 4-74 \text { ) }\end{array}$ & 2.09 & 2.27 & 2.38 & 2.53 & 0.26 & 0.30 \\
\hline
\end{tabular}

${ }^{1}$ see Table $1 ;{ }^{2}$ expressed as kg of gain: $\mathrm{kg}$ of total DMl ratio; ${ }^{3}$ faecal scoring: 1 = normal; 2 = soft to loose; $3=$ loose to watery; 4 = watery, mucous and slightly bloody; 5 = watery, mucous and bloody (Khan et al., 2007); ab - means with different superscripts within a row are significantly different at $P<0.05$ for treatment effect
Table 3. Effect of dietary treatment on structural growth measurements of calves

\begin{tabular}{|c|c|c|c|c|c|c|}
\hline \multirow{2}{*}{ Parameter } & \multicolumn{4}{|c|}{ Treatment $^{1}$} & \multirow{2}{*}{ SEM } & \multirow{2}{*}{$P$-value } \\
\hline & $\mathrm{CON}$ & DMGB & GMDB & DMDB & & \\
\hline \multicolumn{7}{|l|}{ Hip height, cm } \\
\hline $\begin{array}{l}\text { pre-weaning } \\
\text { (days } 4 \text { - 59) }\end{array}$ & 46.4 & 47.0 & 47.4 & 47.3 & 1.09 & 0.61 \\
\hline $\begin{array}{l}\text { post-weaning } \\
\text { (days } 60-74 \text { ) }\end{array}$ & 55.5 & 56.0 & 56.3 & 56.7 & 0.54 & 0.64 \\
\hline $\begin{array}{l}\text { Hip width, cm } \\
\text { pre-weaning } \\
\text { (days } 4-59 \text { ) }\end{array}$ & 22.5 & 22.7 & 23.1 & 22.7 & 0.28 & 0.11 \\
\hline $\begin{array}{l}\text { post-weaning } \\
\text { (days } 60-74 \text { ) }\end{array}$ & 25.0 & 25.1 & 25.0 & 24.9 & 0.18 & 0.76 \\
\hline $\begin{array}{l}\text { Heart girth, cm } \\
\text { pre-weaning } \\
\text { (days } 4-59 \text { ) }\end{array}$ & 14.00 & 14.75 & 14.75 & 15.75 & 1.17 & 0.77 \\
\hline $\begin{array}{l}\text { post-weaning } \\
\text { (days } 60-74 \text { ) }\end{array}$ & 5.37 & 6.62 & 6.62 & 5.50 & 0.46 & 0.13 \\
\hline
\end{tabular}

whereas in DMGB group it was significantly greater $(P=0.03)$ in comparison to CON group during the post-weaning period. FE and the faecal score did not differ among treatments (Table 2). With regard to measurements of structural growth for the preweaning and post-weaning periods, no difference was observed in hip height, hip width and heart girth among the treatments (Table 3). The data show that calves fed DMGB and DMDB had higher $(P<0.01)$ ruminal $\mathrm{pH}$ than $\mathrm{CON}$ group on days 46 and 60 (Table 4). Ruminal $\mathrm{NH}_{3}-\mathrm{N}$ concentration in $\mathrm{CON}$ and DMDB groups was significantly higher $(P=0.04)$ as compared to the DMGB and GMDB groups on day 70 (Table 4).

With advancing age, blood glucose concentrations were decreased in all calves, whereas blood BUN and BHBA concentrations were increased $(P<0.05$ according to repeated measured ANOVA). Concentrations of blood glucose, BUN and BHBA (Table 5) were affected in examined calves. Blood glucose was affected on day 46 of age but no

Table 4. Effect of dietary treatment on rumen $\mathrm{pH}$ and $\mathrm{NH}_{3}-\mathrm{N}$ of calves

\begin{tabular}{|c|c|c|c|c|c|c|}
\hline \multirow{2}{*}{ Indices } & \multicolumn{4}{|c|}{ Treatment $^{1}$} & \multirow{2}{*}{ SEM } & \multirow{2}{*}{$P$-value } \\
\hline & $\mathrm{CON}$ & DMGB & GMDB & DMDB & & \\
\hline \multicolumn{7}{|l|}{ Ruminal pH } \\
\hline day 46 & $5.88^{b}$ & $6.38^{\mathrm{a}}$ & $6.16^{\mathrm{ab}}$ & $6.26^{\mathrm{a}}$ & 0.11 & 0.05 \\
\hline day 60 & $5.78^{b}$ & $6.52^{\mathrm{a}}$ & $6.00^{\mathrm{ab}}$ & $6.43^{\mathrm{a}}$ & 0.18 & 0.04 \\
\hline day 74 & 5.94 & 6.37 & 6.34 & 6.35 & 0.14 & 0.14 \\
\hline \multicolumn{7}{|c|}{ Ruminal $\mathrm{NH}_{3}-\mathrm{N}, \mathrm{mmol} \cdot \mathrm{I}^{-1}$} \\
\hline day 46 & 8.14 & 9.97 & 7.95 & 9.97 & 0.73 & 0.13 \\
\hline day 60 & 7.96 & 7.35 & 5.60 & 7.87 & 1.17 & 0.48 \\
\hline day 74 & $8.31^{a}$ & $6.74^{b}$ & $6.65^{\mathrm{b}}$ & $8.22^{\mathrm{a}}$ & 0.47 & 0.04 \\
\hline
\end{tabular}

${ }^{1}$ see Table 1; ab - means with different superscripts within a row are significantly different at $P<0.05$ 
Table 5. Effect of dietary treatment on blood metabolites for calves

\begin{tabular}{|c|c|c|c|c|c|c|}
\hline \multirow{2}{*}{ Indices } & \multicolumn{4}{|c|}{ Treatment $^{1}$} & \multirow{2}{*}{ SEM } & \multirow{2}{*}{$P$-value } \\
\hline & $\overline{\mathrm{CON}}$ & DMGB & GMDB & DMDB & & \\
\hline \multicolumn{7}{|c|}{ Glucose, $\mathrm{mg} \cdot \mathrm{dl}^{-1}$} \\
\hline day 46 & $113.66^{\mathrm{a}}$ & $102.50^{\mathrm{b}}$ & $103.43^{b}$ & $101.33^{b}$ & 2.57 & 0.02 \\
\hline day 60 & 89.50 & 87.50 & 88.50 & 86.25 & 2.10 & 0.73 \\
\hline day 74 & 89.00 & 86.25 & 89.00 & 87.25 & 2.99 & 0.89 \\
\hline \multicolumn{7}{|c|}{$\mathrm{BUN}, \mathrm{mg} \cdot \mathrm{dl}^{-1}$} \\
\hline day 46 & 9.55 & 9.15 & 8.38 & 9.66 & 1.03 & 0.81 \\
\hline day 60 & 10.22 & 9.20 & 8.25 & 10.87 & 1.36 & 0.56 \\
\hline day 74 & $15.38^{a}$ & $12.73^{b}$ & $11.87^{\mathrm{b}}$ & $13.58^{\mathrm{ab}}$ & 0.65 & 0.01 \\
\hline \multicolumn{7}{|c|}{$\mathrm{BHBA}, \mathrm{mg} \cdot \mathrm{dl}^{-1}$} \\
\hline day 46 & $0.12^{c}$ & $0.21^{\mathrm{ab}}$ & b $\quad 0.16^{b c}$ & $0.24^{\mathrm{a}}$ & 0.02 & 0.01 \\
\hline day 60 & $0.25^{b}$ & $0.37^{\mathrm{ab}}$ & b $0.31^{\mathrm{b}}$ & $0.47^{a}$ & 0.04 & 0.01 \\
\hline day74 & 0.48 & 0.55 & 0.41 & 0.52 & 0.06 & 0.42 \\
\hline
\end{tabular}

${ }^{1}$ see Table 1; BUN - blood urea nitrogen; BHBA - $\beta$-hydroxybutyric acid; ${ }^{\text {abc }}$ - means with different superscripts within a row are significantly different at $P<0.05$

significant difference was detected on day 60 and 74. Blood glucose in CON group was significantly lower $(P=0.02)$ in comparison to the other groups. The BUN concentration was lower $(P=0.02)$ in groups DMGB and GMDB in comparison to CON group on day 74 , but no significant difference was detected on day 46, and 60. Blood BHBA concentration was also affected on day 46 and 60 with no significant difference on day 74 . Calves fed DMDB diet had greater $(P=0.01)$ BHBA concentration than those fed CON and GMDB groups on day 46 and 60. Also, DMGB group differ from CON group on day 46.

\section{Discussion}

In this study, starter intake was increased in calves fed DMDB diets compared to those fed other diets during the pre- and post-weaning period. The lower intake of starter and total DM in calves offered ground grain (CON group) than in those offered dry-rolled grains was expected and could be attributed to lower ruminal $\mathrm{pH}$ for $\mathrm{CON}$ than for other diets. Decreased ruminal $\mathrm{pH}$ has been reported to reduce starter consumption in calves (Khan et al., 2011; Beiranvand et al., 2014).

The differences in starch granule size, shape, and interactions between amylose and surface compounds can alter the rate of enzymatic digestion of grain starches and may affect the intake of starter and, thus, calf performance during weaning transition (Kotarski et al., 1992). In agreement with our findings, Kertz et al. (1979) reported that calves fed starter feed with fine particles had lower DMR than those fed large particles. In the current study, calves fed CON diet exhibited decreased values of ADG in comparison to those fed the other diets. Greater ADG in calves feed dry-rolled barley and maize in comparison to $\mathrm{CON}$ group is in agreement with the findings of other researchers (Coverdale et al., 2004; Bateman et al., 2009). All have reported that ADG was improved when calves were fed textured starter but not a fine ground starter. Porter et al. (2007) also showed that greater ADG in neonatal calves fed coarse meal diet in comparison to a fine ground diet that had been pelleted. Our results are in accordance with those of Coverdale et al. (2004), who found an increase in ADG when calves were fed textured starter in comparison to a finely ground starter. The lower values of ADG in calves fed CON diets might have resulted from the lower values of DMI in CON calves. Previous studies (Coverdale et al., 2004) have shown that there were no significant decreases in FE in calves and goats fed diets with coarse starter, which is in line with our findings.

In the current study, ruminal $\mathrm{pH}$ was lower in calves fed ground grain diets than in those fed dryrolled grain diets. It is well known that dry-rolling would ensure a larger particle size of grain than grinding (Beauchemin et al., 2001; Dehghan-banadaky et al., 2007). Furthermore, grinding increases microbial fermentation by reducing particle size (Bertipaglia et al., 2010) and diets with fine particle sizes decrease rumen pH (Ghassemi Nejad et al., 2012). Pezhveh et al. (2014) reported that greater proportion of larger size particles in the ration (including whole grains) not only affects the rumen fermentation, but also causes mechanical abrasion of the epithelium, thus preventing keratinization. Previous studies indicated that grain processing level influenced rumen $\mathrm{NH}_{3}-\mathrm{N}$ concentration (Lesmeister and Heinrichs, 2004). Shabi et al. (1999) reported that as grinding increases fermentability of grain starch in the rumen, the utilization of $\mathrm{NH}_{3}-\mathrm{N}$ for microbial protein synthesis could have been greater in ground grains as compared to rolled grains resulting in lower $\mathrm{NH}_{3}-\mathrm{N}$ in ground diets than in rolled diets. Knowing the differences in particle size between rolled and ground diets and the expected differences in rates of starch fermentation between barley and maize, we hypothesized that rumen $\mathrm{NH}_{3}-\mathrm{N}$ levels in calves fed dry-rolled diets (maize or barley) would be lower in comparison to those fed ground diets (barley or maize).

Mean blood glucose concentrations in all cases were within the normal range (Nemati et al., 2015; Moeini et al., 2016), which later decreased as calf 
aged regardless their dietary treatment. This reduction in glucose could be attributed to the physiological shift in the primary energy source from glucose to VFA(Hammon et al., 2002). Our findings are in line with those reported by Khan et al. (2011), who also observed decreased the level of blood glucose concentrations in aging calves. Consistently, increasing blood BHBA level as calves aged (Coverdale et al., 2004; Naeem et al., 2012) was mainly attributed to a shift in the physiological fuel sources during the transition from liquid to solid diets (Khan et al., 2011). When there is an excess of nitrogen relative to energy in the rumen, ruminal $\mathrm{NH}_{3}-\mathrm{N}$ concentration increases. Unused ruminal ammonia enters the portal blood through the rumen wall and is transported to the liver where it is detoxified by conversion to urea. As a result of these metabolic transactions, BUN is highly correlated with ruminal ammonia (Hennessy and Nolan, 1988). Therefore, the lower concentrations of BUN for grinding than for rolling in the present study might be related to lower ruminal $\mathrm{NH}_{3}-\mathrm{N}$ concentration. The higher blood BHBA levels (an indicator of metabolic function of the rumen wall) for rolling than for grinding suggested that rumen walls of calves fed dry-rolled diets were more efficient in converting butyrate to BHBA (Khan et al., 2011).

\section{Conclusions}

Feeding calves with starter diets containing dryrolling maize and barley grain similarly affects weaning body weight, final body weight, starter intake and average daily gain as compared to starter diets with ground maize/dry-rolling barley and dry-rolling maize/ground barley. Regardless of grain source, dryrolling improved dairy calves' performance during the pre- and post-weaning periods than grounding.

\section{Acknowledgments}

The authors would like to thank Sari Agricultural Science and Natural Resources University (SANRU) and Mahdasht Milk and Meat Company (Sari, Mazandaran, Iran) for providing research facilities.

\section{References}

AOAC, 1990. Official Methods of Analysis of the Association of Official Analytical Chemists. $15^{\text {th }}$ Edition. Arlington, VA (USA)

AOAC International, 2002. Official Methods of Analysis of AOAC International. Vol. 1. $17^{\text {th }}$ Edition. Gaithersburg, MD (USA)
ASAE, 1983. Method of determining and expressing fineness of feed materials by sieving. ASAE standard S319, in: Agricultural Engineers Yearbook of Standards, p. 325 (American Society of Agricultural Engineers)

Baldwin R.L. $4^{\text {th }}$, McLeod K.R., Klotz J.L., Heitmann R.N., 2004. Rumen development, intestinal growth and hepatic metabolism in the pre-and postweaning ruminant. J. Dairy Sci. 87, E55-E65

Bateman H.G. $2^{\text {nd }}$, Hill T.M., Aldrich J.M., Schlotterbeck R.L., 2009. Effects of corn processing, particle size, and diet form on performance of calves in bedded pens. J. Dairy Sci. 92, 782-789

Beauchemin K.A., Yang W.Z., Rode L.M., 2001. Effects of barley grain processing on the site and extent of digestion of beef feedlot finishing diets. J. Anim. Sci. 79, 1925-1936

Beiranvand H., Ghorbani G.R., Khorvash M., Nabipour A., Dehghanbanadaky M., Homayouni A., Kargar S., 2014. Interactions of alfalfa hay and sodium propionate on dairy calf performance and rumen development. J. Dairy Sci. 97, 2270-2280

Bertipaglia L.M.A., Fondevila M., van Laar H., Castrillo C., 2010. Effect of pelleting and pellet size of a concentrate for intensively reared beef cattle onin vitro fermentation by two different approaches. Anim. Feed Sci. Tech. 159, 88-95

Coverdale J.A., Tyler H.D., Quigley J.D. $3^{\text {rd }}$, Brumm J.A., 2004. Effect of various levels of forage and form of diet on rumen development and growth in calves. J. Dairy Sci. 87, 2554-2562

Dehghan-banadaky M., Corbett R., Oba M., 2007. Effects of barley grain processing on productivity of cattle. Anim. Feed Sci. Tech. 137, 1-24

Fox D.G., Tylutki T.P., Czymmek K.J., Rasmussen C.N., Durbal V.M., 2000. Development and application of the Cornell University nutrient management planning system - a case study. In: Proceedings of Cornell Nutrition Conference for Feed Manufacturers. Rochester, NY (USA), pp. 288-294

Ghassemi Nejad J., Torbatinejad N., Naserian A.A., Kumar S., Kim J.D., Song Y.H., Ra C.S., Sung K.I., 2012. Effects of processing of starter diets on performance, nutrient digestibility, rumen biochemical parameters and body measurements of Brown Swiss dairy calves. Asian-Austral. J. Anim. Sci. 25, 980-987

Gimeno A., Al Alami A., Abecia L., de Vega A., Fondevila M., Castrillo C., 2015. Effect of type (barley vs. maize) and processing (grinding vs. dry rolling) of cereal on ruminal fermentation and microbiota of beef calves during the early fattening period. Anim. Feed Sci. Tech. 199, 113-126

Greenwood R.H., Morrill J.L., Titgemeyer E.C., Kennedy G.A., 1997. A new method of measuring diet abrasion and its effect on the development of the forestomach. J. Dairy Sci. 80, 2534-2541

Hammon H.M., Schiessler G., Nussbaum A., Blum J.W., 2002. Feed intake patterns, growth performance, and metabolic and endocrine traits in calves fed unlimited amounts of colostrum and milk by automate, starting in the neonatal period. J. Dairy Sci. 85, 3352-3362

Hennessy D.W., Nolan J.V., 1988. Nitrogen kinetics in cattle fed mature subtropical grass hay with and without protein meal supplementation. Aust. J. Agr. Res. 39, 1135-1150

Kertz A.F., Prewitt L.R., Everett Jr. J.P., 1979. An early weaning calf program: summarization and review. J. Dairy Sci. 62, 1835-1843

Khan M.A., Lee H.J., Lee W.S., Kim H.S., Kim S.B., Ki K.S., Park S.J., Ha J.K., Choi Y.J., 2007. Starch source evaluation in calf starter: I. feed consumption, body weight gain, structural growth, and blood metabolites in Holstein calves. J. Dairy Sci. 90, 5259-5268

Khan M.A., Weary D.M., von Keyserlingk M.A.G., 2011. Hay intake improves performance and rumen development of calves fed higher quantities of milk. J. Dairy Sci. 94, 3547-3553 
Kotarski S.F., Waniska R.D., Thurn K.K., 1992. Starch hydrolysis by the ruminal microflora. J. Nutr. 122, 178-190

Lesmeister K.E., Heinrichs A.J., 2004. Effects of corn processing on growth characteristics, rumen development, and rumen parameters in neonatal dairy calves. J. Dairy Sci. 87, 3439-3450

Moeini H., Mahdavi A.H., Riasi A., Ghorbani G.R., Oskoueian E., Khan M.A., Ghaffari M.H., 2016. Effects of physical form of starter forage provision to young calves on blood metabolites, liver composition and intestinal morphology. J. Anim. Physiol. Anim. Nutr. doi:10.1111/jpn.12485

Naeem A., Drackley J.K., Stamey J., Loor J.J., 2012. Role of metabolic and cellular proliferation genes in ruminal development in response to enhanced plane of nutrition in neonatal Holstein calves. J. Dairy Sci. 95, 1807-1820

Nemati M., Amanlou H., Khorvash M., Moshiri B., Mirzaei M., Khan M.A., Ghaffari M., 2015. Rumen fermentation, blood metabolites, and growth performance of calves during transition from liquid to solid feed: effects of dietary level and particle size of alfalfa hay. J. Dairy Sci. 98, 7131-7141

NRC, 2001. Nutrient Requirements of Dairy Cattle. $7^{\text {th }}$ revised Edition. National Academy Press. Washington, DC (USA)
Owens F.N., Secrist D.S., Hill W.J., Gill D.R., 1997. The effect of grain source and grain processing on performance of feedlot cattle: a review. J. Animal Sci. 75, 868-879

Pezhveh N., Ghorbani G.R., Rezamand P., Khorvash M., 2014. Effects of different physical forms of wheat grain in corn-based starter on performance of young Holstein dairy calves. J. Dairy Sci. $97,6382-6390$

Porter J.C., Warner R.G., Kert A.F., 2007. Effect of fiber level and physical form of starter on growth and development of dairy calves fed no forage. Prof. Anim. Sci. 23, 395-400

Shabi Z., Bruckental I., Zamwell S., Tagari H., Arieli A., 1999. Effects of extrusion of grain and feeding frequency on rumen fermentation, nutrient digestibility, and milk yield and composition in dairy cows. J. Dairy Sci. 82, 1252-1260

Van Soest P.J., Robertson J.B., Lewis B.A., 1991. Methods for dietary fiber, neutral detergent fiber, and nonstarch polysaccharides in relation to animal nutrition. J. Dairy Sci. 74, 3583-3597

Zhang Y.Q., He D.C., Meng Q.X., 2010. Effect of a mixture of steamflaked corn and soybeans on health, growth, and selected blood metabolism of Holstein calves. J. Dairy Sci. 93, 2271-2279 